\title{
Learning on Lean Production: A Review of Opinion and Research within Environmental Constraints
}

\author{
Rahul S. Mor \\ Department of Industrial \& Production Engineering \\ National Institute of Technology, Jalandhar, India \\ Email: rahul.ip.13@nitj.ac.in (Corresponding Author) \\ Sarbjit Singh \\ Department of Industrial \& Production Engineering \\ National Institute of Technology, Jalandhar, India \\ Arvind Bhardwaj \\ Department of Industrial \& Production Engineering \\ National Institute of Technology, Jalandhar, India
}

\begin{abstract}
Despite of its type, location or principal market base, today the manufacturing enterprises are bound to adopt sustainable practices like lean principles, integration of processes and inter-organizational collaborations to meet their corporate goals. The majority of studies usually discuss either a system or a subcomponent of the production systems and manufacturing strategies in literature w.r.t. lean production; but the rational (what, why, how) behind each production activity seems to be missing. This paper addresses a comprehensive assessment of the literature on lean production in relation to the green concept, for its significance, feasibility and need for organizations to sustain in the global market. Findings of the review reveal that lean principles along with green model can improve the process flow \& employee morale and lower the environmental regulatory non-compliance risk. Further, the environmental and human health risks are often not explicitly considered in lean initiatives that can affect customers \& stakeholders throughout the product life cycle, and the manufacturing enterprises working with lean strategies have the possibility of costs sub-optimization and waste reduction from a lifecycle viewpoint.
\end{abstract}

Keywords: environment, lean production, sustainability, wastes

\section{INTRODUCTION}

While considering the rest of world in their competitive strategy analysis, the enterprises cannot isolate the external factors such as economic trends, competitive positions or technology advancement; and the major factor to remain competitive in the industrial environment of varying needs is the effective \& efficient operation of customized manufacturing system, as well as its ability to quickly re-organize the system for new product introduction. One such set of tools 'lean manufacturing' causes work in a process to be executed with least non-value adding activities (NVAs) and hidden wastes, focusing on quickly meeting the customer demands at minimum time \& cost. Toyota production system (TPS) commenced the lean principles in
1950 in Japan (Womack et al., 1990), as a set of practices \& methodologies that leads to cost reduction. Lean manufacturing (LM) was originally applied to the automotive sector, but Baines et al. (2006) illuminated that lean principles could also be transferred readily to other production functions and sectors. LM principles involve defining customer value, making customer pull the product, value stream and making it flow, and striving for excellence (Jensen et al., 2007). For lean, the continuous improvement feature becomes the compelling power for researchers to discover it further for products and machine tools, concentrating at not only dipping but eliminating all forms of NVA work in production system and improving overall productivity by adding customer value (Figure 1). LM is identified for its focus on reduction of the Toyota's eight types of wastes (Dimitrov et al., 2012) where waste is anything that does not add value to the end product as of customer viewpoint (Meyers et al., 2002). These recognized wastes in TPS are transportation, overproduction, waiting, over processing, motion, defects and unutilized or unused creativity. Thus, LM can be defined as a systematic approach to recognize and eradicate waste through continuous improvement by making the product run at customer demand (Syed et al., 2011). Lean production involves respect for people, a level of patience, continual improvement and a focus on process $\&$ ability to realize the individual development (Liker, 2004). The two pillars of TPS are continual improvement (i.e. Kaizen) and respect for people, and these tools are designed to make it simple to see problems, easy to resolve them and easy to learn from mistakes.

Being the system thinkers, an industrial engineer's approach to ecologically-responsible designs \& manufacturing practices must incorporate the employee, environment and their interaction for optimal ergonomic efficiency with least disturbance to the environment. Mr. Suzuki, senior environmental official at Honda, studied whether lean practices help to achieve environmental performance or they are obstacles, and he believed that lean stresses on the abilities of individual worker rather than 
viewing them as an extension of production system. Seuring et al. (2004) indicated that in the last decades environmental questions became a critical issue for governments and enterprises; moreover it has become a concept that polluting environment could harm the company image among consumers, what could adversely affect profitability \& sales, and now the ecological challenges are no longer limited to the manufacturing walls. Pusavec et al. (2010) described the evolution of four production systems according to their environmental practices as:

a) Traditional production systems- based on disposal of wastes as a principle;

b) Lean production systems- waste reduction for better resource utilization;

c) Green production systems- apply the 3 R's principle (Reduce, Reutilize or Recycle wastes);

d) Sustainable production systems- apply the 6 R's principle (Reduce, Reutilize, Recycle, Recover, Redesign and Re-manufacture).

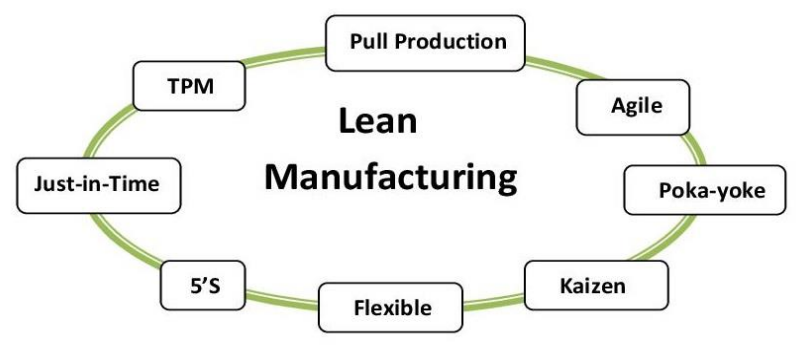

Figure 1 Lean Manufacturing

Though, one weakness of lean is that, regardless of the process approach that aims at reducing the risk of suboptimization, it primarily focuses on the production part of the lifecycle, and an organization working with this approach risks sub-optimization of costs from a life-cycle perspective. When companies have limited time and resources, efforts should be placed where they contribute the most, which is not always in the production phase. Another potential weakness of lean is that Just-in-Time (JIT) can lead to increased shipment, as pointed out by Whitelegg (1994) and Bleijenberg (1996), this is however not perceived as a problem by the interviewed companies as transport is strongly linked to costs that can be very low through proper planning and managing the transports. Larson et al. (2004) revealed that lean can lead to a lack of consideration of ecological risk, that the companies' activities may cause risk remaining hidden.

\subsection{Need for Lean and Environment Integration}

Clearly considering the environmental goals and opportunities in implementation, lean improves process flow, lowers the regulatory non-compliance risk and improves employee morale which is only possible with full regulatory obligations. Currently, there is an emphasis on lean thinking surrounded by the environment, health \& safety as well (Brewer et al., 2012), and adopting green practices are not only good for sustainability reasons but are also good business (Green Manufacturing, 2008). Studies show that the 'envi-lean' integration is not only possible but also advantageous from business and an environmental viewpoint while reducing the risk of sub-optimization and synergies can be achieved (Gadekar, 2015; Bergmiller et al., 2009; Puvanasvaran et al., 2012). Larson et al. (2004) found that combining lean \& environmental methods is not only possible, but it also offers the potential to gain competitive advantages and environmental sustainability. Furthermore, combining the two methods would support lean on the aspects where it has been considered weak i.e. the life-cycle view and awareness of environmental risks (Table 1). The polluter pays principle (PPP), also known as extended producer responsibility (EPR), emphasizes that the summation of all environmental costs throughout the life cycle of any product should be reflected in the market price of that product (Roosen et al., 2013). This would mean that manufacturers would absorb greater responsibility in cleaning, storing, recycling, and reuse of produced waste that leads to national policy formulation, and hence to include the environmental waste into lean thinking.

Table 1 Lean Efforts \& Their Affects

\begin{tabular}{|c|l|c|}
\hline Sr. No. & \multicolumn{1}{|c|}{ 'Envi-lean' efforts } & After affects \\
\hline 1. & $\begin{array}{l}\text { Less scrap, fewer defects } \\
\text { and less spoilage }\end{array}$ & $\begin{array}{c}\text { Reduced environmental } \\
\text { waste }\end{array}$ \\
\hline 2. & $\begin{array}{l}\text { Fewer defects, no over- } \\
\text { production and simpler } \\
\text { \& right-sized products }\end{array}$ & $\begin{array}{c}\text { Reduced use of raw } \\
\text { materials }\end{array}$ \\
\hline 3. & $\begin{array}{l}\text { Less storage and no } \\
\text { inventory space needed }\end{array}$ & $\begin{array}{c}\text { Reduced material, land } \\
\text { \& energy use }\end{array}$ \\
\hline 4. & $\begin{array}{l}\text { No over-production, no } \\
\text { lighting/heating/cooling, } \\
\text { no extra space and no } \\
\text { over-sized equipment }\end{array}$ & Less energy use \\
\hline 5. & $\begin{array}{l}\text { No over-processing and } \\
\text { more efficient transport } \\
\text { \& movement }\end{array}$ & Lower emissions \\
\hline
\end{tabular}

Authors have presented lean manufacturing strategy in a structured sense, and an attempt has been made in this paper to categorize the literature along-with leading conceptual and research methodological dimensions to trim down the wastes \& loss of economy to enterprises, by integrating the environmentally-lean (envi-lean) model. This paper reviews the literature of last twenty years (starting from 1995 to 2015), as economic reforms were initiated in the nineties in India, and TPS was identified as lean also in the 1990s; now we want to assess its development, implementation and affects after twenty years. Section 1 of this review provides the comprehensive background of 'lean production and environment' detailing the emergence of the theme and the need to integrate envi-lean; Section 2 is the review methodology with grouping of previous studies, findings, philosophies, core principles and characteristics of the subject along with justification. Section 3 includes classification of articles gathered for this study detailed in preceding chapter with a view to generate common perspective and opinion; while Section 4 discusses the findings from review so as to compare and contrast the issues while also recognizing suggestions to develop 'envilean' environment in an enterprise; finally, Section 5 is the conclusion part of the review. Further, an Appendix- I is also given at the end of this paper to list down the details of all the reviewed articles. 


\section{REVIEW METHODOLOGY}

Literature review is a research methodology and the content analysis of historical papers/literature has been applied in this paper so as to create the replicable and valid implications from contents for their use (Krippendorff, 2004). Content analysis is a scientific method for briefing, quantitative analysis of messages, many words of text into fewer content groupings based on explicit coding rules (GAO, 1996 and Weber, 1990); whereas, Holsti (1969) defines content analysis as 'a technique for building inferences by objectively and scientifically identifying specific characteristics of messages'. Thus, content analysis is a research tool that determines the presence of certain words or theories within texts or a set of texts. In this paper, the target population is the published articles on various databases, followed by the sampling procedure.

In order to facilitate a clear 'line-of-sight' from information basis and comprehensive overview of the previous research findings, methodologies/reviews of lean production along with environmental concerns, a sample size of about 110 articles has been taken followed by the deductive approach in selecting and evaluating the body of literature on 'envi-lean'. The search for publications within defined boundaries has been executed on the scientific databases like Google scholar, Web of Science, Open access journals, Scopus and Online journal search engine; by searching the article title, abstract fields and keywords; and then limited by certain criteria such as the year of publication, subject areas, document type. The databases search offered numerous publications, which has been reduced to 110 after applying the limiting criteria.

\subsection{Coding and Categorization}

Categorization of the content is very important in content analysis, which is defined by Sarantakos (2005) as a set of criteria or standard that is incorporated about a theme or value. Categories used in the content analysis are supposed to be very clear and should enable other researchers to have identical outcomes while re-examining the same data with defined categories (Fraenkel and Wallen, 2005). The categories in this paper are determined by probing the literature, reviews and researches regarding the 'lean production and green' concept. After accumulating the research topic categories from the study of Burgess et al. (2006), a codebook has been developed to employ as a coding instrument, where codebook is an instrument that includes all of the operational definitions of variables (Neuendorf, 2002). All the selected articles were further integrated into the defined framework of four categories of variables i.e. descriptive features, definitional issues, theoretical concerns and research approaches for the conceptualization and methodological analysis (Table 2).

Table 2 Literature Review Classification Framework

\begin{tabular}{|c|l|l|l|}
\hline No. & Grouping & \multicolumn{1}{|c|}{ Content covered } & \multicolumn{1}{|c|}{ Basis } \\
\hline 1. & $\begin{array}{l}\text { Descriptive } \\
\text { features }\end{array}$ & $\begin{array}{l}\text { Title, country, industry, year, } \\
\text { sector, journal }\end{array}$ & Express the features of sample articles. \\
\hline 2. & $\begin{array}{l}\text { Definitional } \\
\text { issues }\end{array}$ & $\begin{array}{l}\text { Approaches, conceptual framing, constructs, } \\
\text { discipline, process }\end{array}$ & $\begin{array}{l}\text { Discover stability or variation in 'envi-lean' definitions to various } \\
\text { dimensions. } \\
\text { Classify the area that researchers argue falls in lean production. }\end{array}$ \\
\hline 3. & $\begin{array}{l}\text { Theoretical } \\
\text { concerns }\end{array}$ & $\begin{array}{l}\text { Purpose, strategy, range, } \\
\text { application, function }\end{array}$ & $\begin{array}{l}\text { Establish the range of theories used to enlighten lean and their } \\
\text { applications. }\end{array}$ \\
\hline 4. & $\begin{array}{l}\text { Research } \\
\text { approaches }\end{array}$ & $\begin{array}{l}\text { Modeling, research methods, hypothesis, case } \\
\text { study }\end{array}$ & $\begin{array}{l}\text { Determine the assumptions and research methods used to define } \\
\text { lean'. }\end{array}$ \\
\hline
\end{tabular}

Reference: Burgess, Singh and Koroglu (2006).

Particularly, the grouping 1 provides an examination of the sample articles/theories expressing its features \& trends in the literature like title, year of publication, industry/sector to which the study is applied; grouping 2 discovers the area of supply chains covered by researchers from a range of perspective using either new or existing organizing designs, processes employed; while grouping 3 also illuminates the literature dealing with the issues more or less related to the theoretical bases such as strategies applied or the purpose of study, application of research \& its scope; finally, grouping 4 examines the issues associated with research methodology and assumptions used, hypothesis, modelling.

\subsection{Validity and Reliability}

Validity may be stated as the degree to which a measuring method represents the intentional, or it is the quality of research results that directs us to suppose them as realistic, and the external validity is associated to whether the sample of study corresponds to the population or not (Neuendorf, 2002 and Krippendorff, 2004). In this paper, all the population i.e. articles integrating lean with the environmental concept and in the context of diverse continents is included and hence, the external validity is assured. Then face validity is confirmed that whether the instrument measures exactly what it is planned to assess or not, and agrees with the results if reasonable (Neuendorf, 2002 and Krippendorff, 2004). The category table has been checked by the experts, researchers whether it is sufficient to assess the intended figures, and content validity is controlled. An instrument has content validity if it covers all aspects of the subject which it is intended to assess, and hence the defined categories' content validity has been checked by an academician.

Weber (1990) confirms that the categorization procedure must be reliable to make valid inferences from the wording and the reliability issues occur due to the ambiguity of word meanings or category definitions. It is also required to measure the intercoder reliability of content analysis i.e. the amount of concurrence among two or more coders, and a reliability subsample must be assessed randomly to assess it (Lombard et al., 2002; Neuendorf, 2002). Then, coders have to code the documents as indicated in the categories, and also the level of agreement between them needs to be measured. Some measurement techniques for intercoder 
reliability are Percent agreement, Scott's pi, Holsti's method, Krippendorff's alpha and Cohen's kappa (Uysal and Madenoglu, 2015). Percent agreement method has been used in this paper to measure the intercoder reliability, by simply adding up the coded cases in same way by the three raters and dividing by the total number. Finally, the intercoder reliability obtained in this paper is $83 \%$, and thus the data can be deemed as reliable.

\section{ANALYSIS}

The selected articles were integrated into a framework based on various dimensions and classified into four discrete, yet rationally ordered, groupings initiating with least complex perceptions and advanced research issues, and categorized in the following way:

\subsection{Grouping 1: Descriptive Features}

The review shows that over hundred journals covering diverse disciplines were captured, and the International journal of production economics (10); Journals of manufacturing systems, technology \& management (9); Journal of industrial engineering \& management (6); Journal of cleaner production (5); international journal lean thinking (3); and the International conferences on lean production, management \& industrial engineering (18), accounted for $47 \%$ of the total articles, and among which about $78 \%$ studies having special emphasis on envi-lean; whereas the remaining literature appears to be focused in another part of lean like productivity \& quality improvement, setup time reduction, sustainability issues etc. and based on these explanatory feature the reviewed studies are categorized as below:

Keitany and Riwo (2014) explored the inventory management through lean tools, and employed the descriptive research design tool for improving the management approach \& participation of all employees; Baines et al. (2006) studied the application of environmentally \& socially sensitive practices to reduce the negative impact of manufacturing activities and harmonizing the pursuit of economic benefits; Taubitz (2010) stated that safety \& health are the fundamental to sustainable growth but green-lean can result in improved organizational performance \& customer experience; Marvel and Standridge (2009) presented an improved lean process using simulation modelling and experimentation prior to execution; Arlbjørn and Freytag (2013) examined lean in academic literature of 105 international peer-reviewed journals and concluded that only $1 / 3$ of them apply a toolbox view on lean; Castro et al. (2012) reviewed the agile and lean manufacturing concepts along with the information \& commutation technological solutions, to resolve the issues in manufacturing sector; Dakov and Novkov (2007) concluded that lean principles leads enterprises towards a more sustainable processes \& product development; Romvall et al. (2010) indicated that lean \& green are the favorable options for environmental sustainability within production system in Sweden; and Nordhaus (1995) analyzed the role of climate in economic development, its relationship and the prospects for economic impacts. Figure 2 categorizes the percentage of the reviewed studies with respect to their year of publishing, and the graph shows that $70 \%$ studies are published in last five years (2010 - 2014).

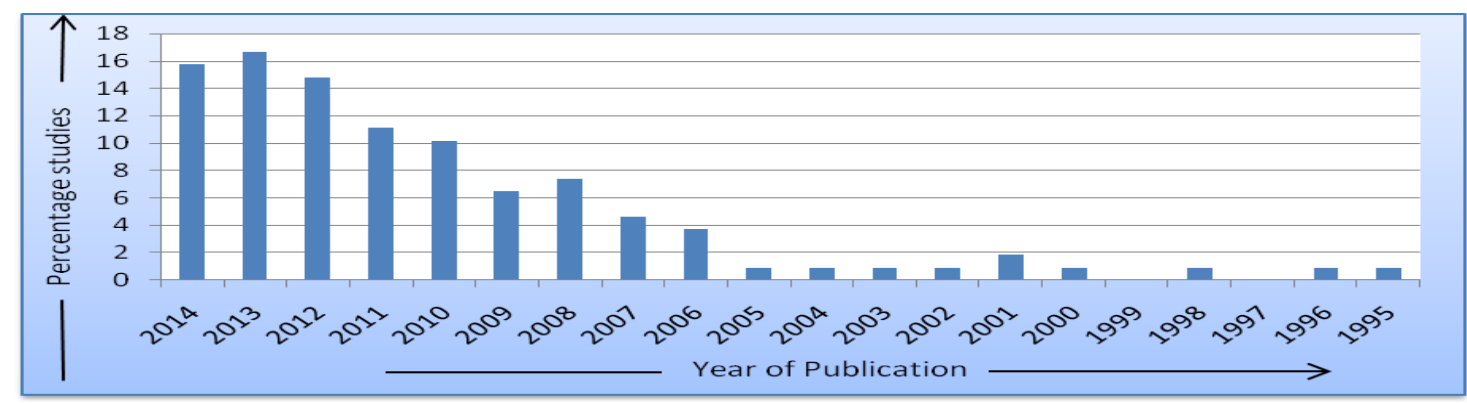

Figure 2 Classification for Year-wise Studies

Improving the environmental performance also leads to reducing costs, increase competitiveness and to be more innovative across the value chain; Maia et al. (2013) discussed lean production in textile industry that fosters a sustainable work environment; Chen and Meng (2010) reviewed the course from mass to lean production and issues in Chinese enterprises; Kurdve et al. (2014) focussed on integration of environmental and operations management in two global Swedish companies; Moreira et al. (2010) presented the role of lean for achieving better environmental performance and an emergent business model for supporting eco-efficiency by literature review; Johansson and Sundin (2014) compared lean product development (LPD) and green product development (GPD) concepts through a systematic literature review including 102 journal publications; Holweg (2007) presented the research that led to the formulation and dissemination of the most influential manufacturing paradigms of recent times; while, Ogunbiyi et al. (2013) strained on lean and sustainability reflecting how it impacts on sustainable construction through literature. Figure 3 categorizes the percentage of the reviewed studies with respect to the country/continent, and the graph shows that more than $70 \%$ studies are carried out by European \& Asian authors. 


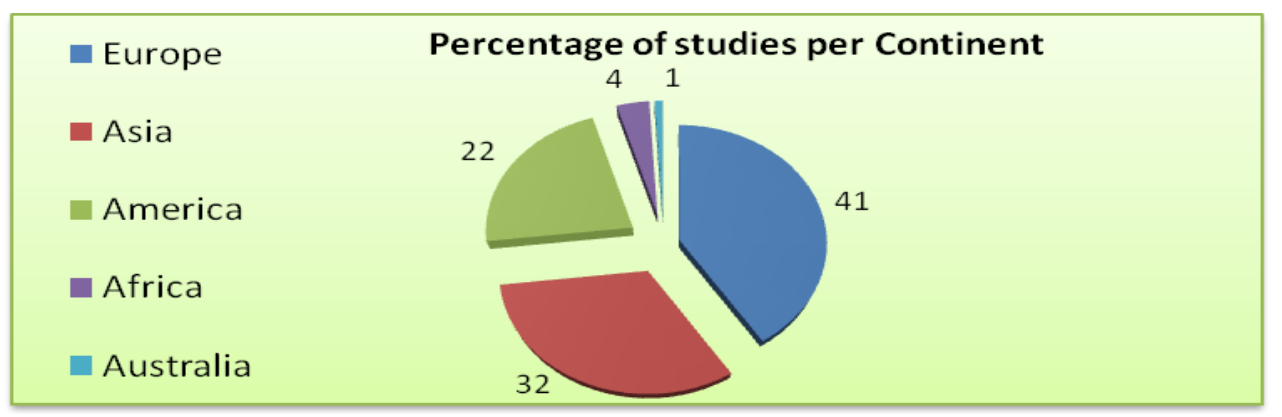

Figure 3 Classification for Continent-wise Studies

Elmoselhy (2013) showed that hybridizing the lean \& agile systems together is technically valid to be implemented in an industrial setting; Yang et al. (2013) presented a multi-objective line-cell conversion model of traditional conveyor assembly line for reducing workers
\& increasing productivity. Figure 4 categorizes the percentage of reviewed studies with respect to the sector/area, and the graph shows that most of the studies have been conducted in manufacturing, automotive, agrifood, transportation \& storage sector.

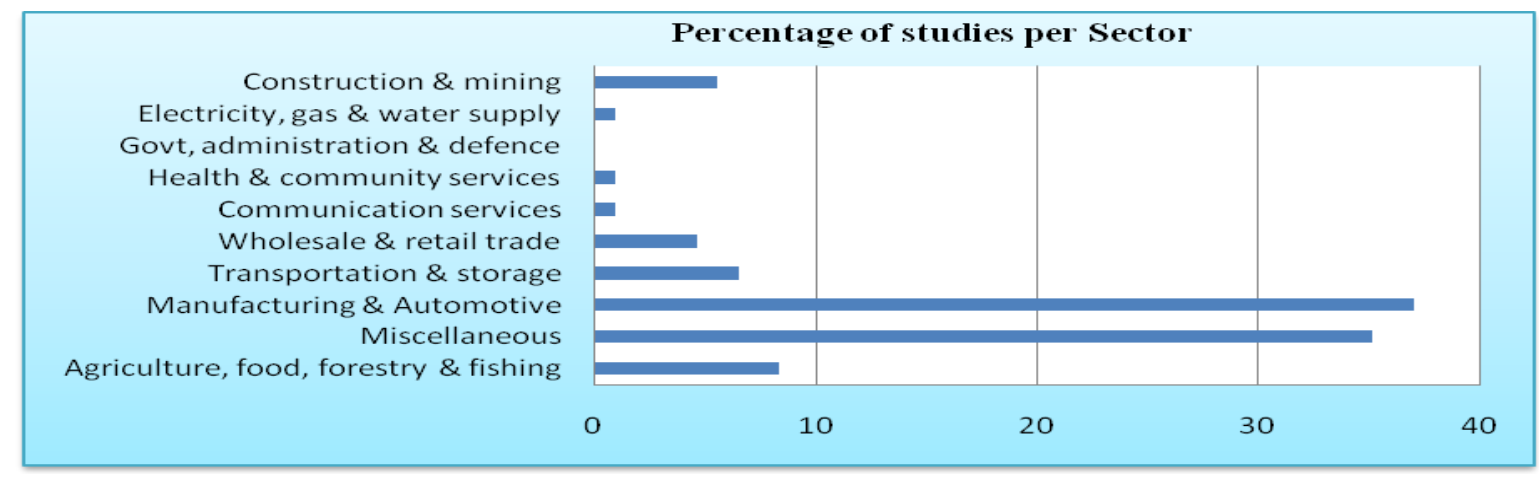

Figure 4 Classification for Sector-wise Studies

Latha and Inbasekaran (2014) explored a framework of new business model for the tanning sector to minimize the environmental impact of manufacturing processes and products; Helldal et al. (31) investigated how lean and environmental aspects affect one another and how they could be integrated into a single model; though, Hidy et al. (2011) presented a comprehensive discussion of hazards associated with disposal of used or waste electronics \& electrical equipment that can be recycled or reused.

\subsection{Grouping 2: Definitional Issues}

There appears a little compromise on various lean production definitions with either a broad view that are perceptible and further classified in this review. A more precise investigation of the relationships in 'envi-lean' definitions exposed that about $55 \%$ of the articles have surrounded within the definitions, key concepts concerning the flow of information and material across associations. Out of the articles, two definitions are proposed by Kurdve (2011); two theories by Marudhamuthul et al. (2011); two definitions by Prasad and Sharma (2014); and two ideas by Puvanasvaran (2012), where all are concerning the green manufacturing and lean principles, their implementation, barriers and key success factors. A conceptual framework is also developed to classify these reviews which show that about $70 \%$ of the articles framed lean as a continuous success practice, $14 \%$ as a system and mostly assumed lean itself as a green activity in the view of an enterprise, and based on definitional issues the reviewed studies are categorized as:

Lean manufacturing, lean enterprise or lean production, is a systemic method for the elimination of waste (Muda), waste created through over-processing or overburden (Muri) and waste created through uneven processes/workloads (Mura) within a manufacturing process (Wikipedia). Lean, a management philosophy derived from TPS (identified as lean in the 1990s) is centered on making evident what adds value to the end product by reducing everything else (Womack and Daniel, 1990; Holweg, 2007), whereas, TPS is known for its focus on the reduction of original Toyota seven wastes for improving the overall customer value, but still there are varying perceptions on how this can be best achieved. Henry Ford, one of the first people to who developed the philosophy behind lean manufacturing through 'continuous flow' concept on the assembly line of an automobile, where he kept the production standards extremely tight, and this resulted in reduced waste; Gustashaw and Hall (2008) conferred lean \& environmental sustainability and broaden the operational considerations from internal efficiency to their effects on external processes; Laird (2012) stated that eliminating energy waste is equally important to industries as a result of rising energy costs; Post and Slaughter (2000) supposed that lean's reduction of inventories \& workers makes it vulnerable and hence the need to replace capitalism with democratic socialism; Puvanasvaran et al. (2012) argued that ISO 14001 standards and lean principles can achieve the continual improvement ideas; Chahal (2012) focussed on 
producing high quality products along with flexible manufacturing that help businesses remain competitive \& sustainable over long term; Bashkite and Karaulova (2012) proposed methodology to facilitate the understanding of TRIZ (Theory of inventive problems-solving) that present the integration model by developing the matrix for contradiction solving of green-lean.

Whitman et al. (2008) presented the existing simulation based virtual factory and the application of modern production systems along with the integration of sustainability; Florida (1996) examined the link between advanced production \& environmentally conscious manufacturing via survey, phone interviews and field research. Pauline (2009) studied the assumption that lean means green because of doing more with less, yet the evidence to support this is mostly anecdotal and the causal link is unproven; Thackeray (2008) expressed that the approach to eliminate waste, reduce cost and improve process has always been a part of what we can now call 'lean green thinking'; Rakshit and Rodrigues (2013) provided a broad perspective on combining lean with environmental sustainability to assist foundries in remaining competitive; Kyrö et al. (2011) illustrated the similarities between lean \& energy management and observed that the policies \& practices bear a clear resemblance to lean principles (Figure 5); Handa et al. (2012) highlighted the interlinks between environmental issues \& manufacturing strategies in enhancing eco-efficiency of manufacturing system and successful implementation beyond small standalone initiatives; Harrington et al. (2005) investigated the factors leading to total quality environmental management driven mostly by supply-side \& demand-side factors that originate internally within the firm; Dües et al. (2013) explored that the implementation of green practices in turn also has a positive influence on existing lean business practices; Ioppolo et al. (2014) presented the preliminary remarks for possible assessment of key factors related to their integration in envi-lean management; Jadhav et al. (2013) explored green lean practices that assist in designing the structurally robust implementation strategies; Kidwell (2006) stated that environmental concerns are a part of the lean concept and air/water emission, generation of solid waste, etc. represents the waste of production; Li et al. (2011) elaborated the concept of lean design, its application fields and indicated that it is the only way to establish lean enterprise that make comprehensive lean design.

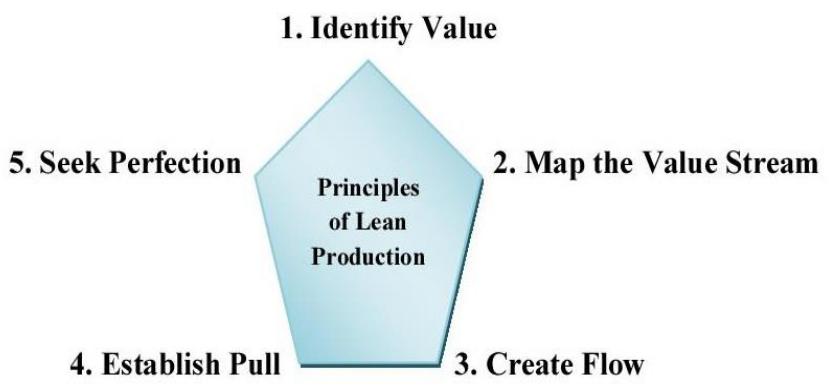

Figure 5 Principles of Lean Production

Carvalho and Machado (2011) explored the possibility to merge lean, agile, resilient and green ideas in supply chain management, where lean-supply-chains seeks waste reduction, agile supply chain (SC) directs rapid-react to market changes, resilient SC responds efficiently to disturbances and the green SC cuts environmental impacts; Demeter and Matyusz (2011) concentrated on how various contingency factors influence the inventory turnover of lean manufacturers through cluster \& correlation analysis; Mcleod (2009) proposed an introductory course for students so as to familiarize with prominent operations Management strategies. Treville and Antonakis (2006) concluded that lean job design may cause worker intrinsic motivation, however, there may be substantial differences in intrinsic motivation under differing lean production configurations; Shah and Ward (2007) clarified the semantic confusion of lean production by an extensive literature review using historical evolutionary perspective; Robert (2008) offered ideas on making lean-to-green work framed by firm's management systems \& business excellence programs driven by continual improvement; Bose and Sinha (2012) investigated the labor impact of lean production to bring high-trust labor relations including labor development alongside economic growth; Sujatha and Basu (2013) concluded that the implementation of environment management system could be conducted in a structured manner by collaborating human resource factors; Puvanasvaran et al. (2012) examined the linkage of lean with ISO 14001 through quantitative research method and questionnaire survey; Prasad and Sharma (2014) concluded that the lean \& green can be integrated and offered simultaneously in the operation management to reduce waste \& pollution; Prasad and Sharma (2014) cleared that lean is a powerful tool and it can create superior financial \& operational outcomes.

\subsection{Grouping 3: Theoretical Concerns}

Popper et al. believed that the theory development is a crucial constraint for the development of any ground; however, some researchers propose that theories should be built upon existing ones. To comprehend lean production, the articles were analyzed to ascertain whether the theories existed or new ones. Comprehensive list of reviews with existing theories were offered in diverse aspects such as economics, application, information, strategic management, sustainability, sociology, functions, and based on these theoretical concerns the reviewed studies are categorized as below:

King (2007) engaged with the transaction cost analysis to hypothesize how collaboration between corporations \& environmental stakeholder groups can be structured; Marudhamuthul and Krishnaswamy (2011) addressed the development of green setting through lean principles in an Indian garment export industry to explore their link; Singh et al. (2010) provided an efficient lean measurement method on various leanness parameters and fuzzy set theory to remove the bias of human judgment \& defuzzification; Nulkar (2014) explored the incidence of environmental performance within various stages of the product life cycle and recommended that there is potential for improvement in Indian SMEs; Jacobs et al. (2010) analyzed the shareholder value effects of environmental performance and market reaction to corporate environmental initiatives, awards \& certifications; Herrmann et al. (2008) presented an analysis of the coherences and interdependencies between lean production \& ecologically oriented variables, specifically 
energy consumption; ElMaraghy and Deif (2014) proposed a dynamic system approach to investigate the challenges of implementing production leveling \& associated costs through a lean cell model and the choice between the 'best lean' \& 'no lean' policies; Torielli (2010) provided view on combining lean methods with environmental sustainability for foundries in remaining competitive; Yang et al. (2011) explored the conflict between lean practices, environmental management and business performance outcomes from 309 multinational companies (MNC) through AMOS; Pampanelli et al. (2011) proposed a model integrating 'envilean' through Kaizen approach in an MNC capable of reducing $30 \%$ material usage, waste generation and annually cost savings of 132 GBP in one operational cell of GKN driveline, America (Figure 6); and Wiengarten and Pagell (2012) investigated the importance of quality Management for environmental initiatives through survey.

Dhingra et al. (2012) supposed that growing energy demand has led to increased global energy production with consequential increase in global warming emissions of $\mathrm{CO}_{2}$ increased by $5.3 \%$ in 2010 to a record 30.4 giga tonnes; Netland and Aspelund (2014) reviewed the key dimensions to explain multi-plant improvement programme results in adopting, acting or avoiding of practices in subsidiaries; Bergmiller and McCright (2009) yielded the similarities between lean \& green theoretical models to develop a comprehensive integrated model; Duarte and Cruz-Machado (2013) examined how diverse business models and frameworks can add value to modelling a lean and green approach; Huang et al. (2009) examined the insights experienced in developing prototype solutions and the schemes for deploying smart objects in manufacturing to achieve real-time traceability \& visibility while minimizing the total cost; Ghosh (2012) examined the current state of lean adoption in Indian manufacturing plants and its impact on operational performance; Ramirez et al. (2014) identified the factors of environmentally-sustainable aids in firms' processes and charted the strategies to beat supplier barriers; Olhager and Parjago (2012) studied 216 Australian automotive firms and found clear difference of improvement initiatives between make-to-order \& make-to-stock firms; Fore and Mbohwa (2010) illustrated the application of cleaner production in foundries in lower income country that impact negatively on the environment leading to unsustainable resource utilization, depletion and pollution; Miller et al. (2010) presented a case study of RCELL projects to avoid over production or under production \& unnecessary energy use; Anand and Kodali (2008) aimed at selecting lean as a strategy \& preference ranking organization method for enrichment evaluations (PROMETHEE) to analyze its impact on stakeholders, through case studies in SMEs.

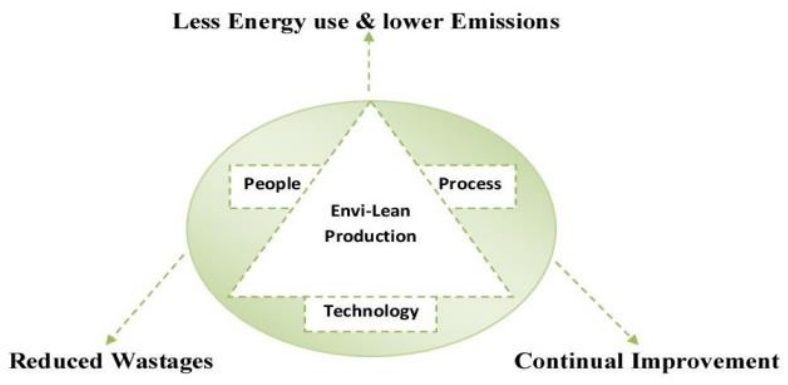

Figure 6 Environmentally-Lean Production
Sawhney (2007) proposed a methodology to clear the link between lean ethics and their ecological impacts through case study in metal cutting industry; Maxwell et al. (1998) covered the organizational decisions to balance productivity \& quality goals along with environmental responsibility by case studies at two units of Honda; Rosenbaum et al. (2012) studied the 'green-lean' application in the construction of a hospital to discover environmental or productive waste sources; Galeazzo et al. (2014) argued on execution of green-operation management based on collaboration \& interaction; Silva et al. (2013) studied the green-lean correlation using concept mapping mode in relation to a positive effect on resources \& energy consumption.

\subsection{Grouping 4: Research Approaches}

Studies can be tested using the profile and form of the subsequent knowledge generated assuming scientific method, empiricism, views, phenomena, relationships, and modernism. For this particular parameter, the framework consisting functionalism as well as the fundamental humanism and structuralism was employed, and based on these research approaches the reviewed studies are categorized as below:

Liu et al. (2014) developed a non-dominant sorting genetic algorithm to attain Pareto front and to diminish total non-processing electricity consumption as well as the total weighted delay in a job shop; Ahemad et al. (2013) highlighted the weak areas as potential for company to improve green manufacturing execution through case study in Indian steel industry; Elsayed et al. (2013) discussed a 3step approach for proactive performance assessment of green-lean through case study in an automotive, resulting $10.8 \%$ drop in production cost; Salleh et al. (2012) studied the green lean total quality information management system via questionnaire in 30 automotive vendors in Malaysia; Esmer et al. (2010) intended to find out the optimal number of handling equipment $\&$ reduced the ecological harm of Turkish container terminal via a simulation model; Abdulmalek and Rajgopal (2007) applied the value stream mapping (VSM) \& simulation model to contrast the before $\&$ after state in an integrated steel mill; Purvis et al. (2014) explored the flexibility in context of lean, agile \& leagile supply networks and investigated the vendor \& sourcing flexibility in two UK based specialist fashion retailers; Vivek and Ravindran (2008) emphasized the impact of environmental uncertainty on the lean practices followed by small manufacturing firms; Satao et al. (2012) reviewed on how green manufacturing can be achieved through lean in order to prevent pollution \& protect environment.

Roosen and Pons (2013) offered a method to integrate environmental waste into lean through VSM in manufacturing setting for carbon footprint; Omer (2008) reviewed the literature on energy sources, environment \& sustainable development for reducing fossil energy use and to promote the green energies in construction sector; Venkat and Wakeland (2006) investigated the environmental performance for $\mathrm{CO}_{2}$ emissions using simulation model and suggested that it is quite possible for lean $\&$ green to be in clash that leads to tradeoffs and further chances for optimization; Hibadullah et al. (2013) explored the relationship between lean and environmental performance in 
Malaysian automotive industry by structural equation modelling (SEM); Yang et al. (2010) hypothesized that environmental management is partially an extension of advanced manufacturing practices and found that the electronic \& electrical industries in China \& Taiwan have developed their own practices; Herron and Hicks (2008) disseminated the selected lean techniques in companies of north-east England to improve productivity and obtained the savings as eight times greater than total costs from 15 companies; Khalid (2011) suggested the motion study to achieve company goals and ARENA software to simulate the inspection lanes at Motor Vehicle Periodic Inspection station and yielded an expected improvement of $174.8 \%$ in production capacity.

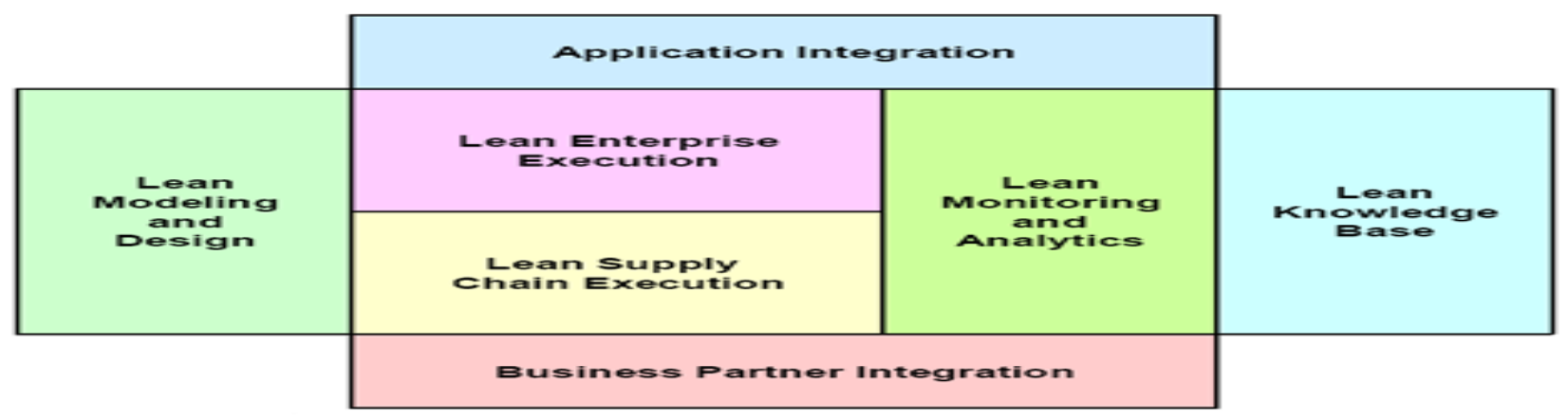

Figure 7 Lean Production Framework

Kurdve et al. (2011) dealt with the environmental value stream mapping for achieving better results in two case studies at Volvo; Nasab et al. (2013) introduced an integrated dynamic approach to investigate the technology effectiveness of lean manufacturing in enterprises and ability to alter the parameter's affects on others; Venkataramana et al. (2014) aimed at lean implementation in an Indian automotive industry through multi-criteria decision making model \& analytical hierarchy process to create product mix flexibility; Marudhamuthu et al. (2011) addressed the lean implementation in an Indian garment export industry by VSM and single minute exchange of die (SMED) approaches which resulted in reduced set up time; Mittal and Sangwan (2014) developed a model for environmentally conscious manufacturing by SPSS tool, exploratory \& confirmatory factor analysis and SEM to validate the model; Taggart and Kienhöfer (2013) concluded that lean audits are only effective ways to measure improvements in operational performance and tested it in 64 manufacturing sites; Sullivan et al. (2002) provided a roadmap for the analysis of equipment replacement decision problems through VSM; Wang et al. (2008) introduced a step-by-step implementation framework for lean production $\&$ product development by means of marketing research on product development \& design processes (Figure 7); Upadhye et al. (2014) tried to find out the implementation enablers of lean tools i.e. Just-in-Time in the Indian corrugated packaging industry through interpretive structural modeling; Jaganathan (2014) carried out the assembly line balancing \& layout modification in a garment industry using largest candidate algorithm rule, and increased the efficiency up to $26 \%$ \& the productivity by $25 \%$.

Finally, current trends in lean production research incorporate the development of productivity \& quality improvement processes within environmental boundaries; on the other hand, sustainability, integrated manufacturing, deployment of information technology to reduce manufacturing lead time, and human health issues have also been placed on priority by authors.

\section{DISCUSSION}

Based on the findings of the review, it is possible to discuss the issues like how to conceptualize and develop the field and evaluate the impact of the various trends in lean production research. The review also indicates that many other sectors like government, health services, construction, communication and industrial markets do not yet appear to have researched comprehensively. Apart from this, some findings of the review are as:

a) Despite of the process approach, lean production primarily focuses at reducing the risk of suboptimization and the production part of the lifecycle; thus, the associations working with lean have the possibility of costs sub-optimization from a life-cycle viewpoint.

b) Lean along with green concept improves the pr ocess flow \& employee morale, and also lowers the regulatory non-compliance risk. Adopting green practices are not only good for sustainability but are also good for business value.

c) There is a need to include environmental waste along with other lean wastes where focused waste management requires shop floor people, engineers, and management to know what \& where the waste is being generated.

d) Lean can be leveraged to create even more improvement by addressing the environmental 'blind spots' as they are often suppressed in overhead \& facility support costs.

e) The environmental \& human health risks are often not explicitly considered in lean initiatives that can affect customers \& stakeholders throughout the product life cycle.

f) The more difficult problem to overcome waste is the lack of vertical integration between the organizational data on environmental waste and the processes that created the waste.

\section{CONCLUSION}

After the comprehensive literature assessment, it is concluded that the human health \& environmental issues, 
improved product quality and the associated economic benefits in sustainable production systems can be achieved through lean principles that eliminate uncertainties in processes, reduce wastes and non-value adding activities; and integrated product development and manufacturing processes along with the interoperability of information systems can enhance the business value in production systems.

\section{ACKNOWLEDGMENTS}

The authors would like to express their sincere gratitude for the remarks and suggestions made by the reviewers, which radically improved this paper.

\section{REFERENCES}

Baines, T.S., Lightfoot, H.W., Williams, G.M. and Greenough, R.M. (2006). State-of-the-art in lean design engineering: a literature review on white collar lean. Proc. IMechE, Part B: Journal of Engineering Manufacture, 220(9), pp. 1539 1547.

Bergmiller, G.G. and Mccright, P.R. (2009). Parallel models for lean and green operations. Proceedings of Industrial Engineering Research Conference.

Bleijenberg, A. (1996). Freight Transport in Europe: In Search of a Sustainable Course. Delft: Centrum Voor Energiebesparing en Schone Technologie (CE).

Brewer, A.S. and Pojasek, R.B. (2012). Assessing environmental sustainability performance at the national level environmental quality management. Winter pp. 33 - 47, DOI: $10.1002 /$ tqem.

Burgess, K., Singh, P.J. and Koroglu, R. (2006). Supply chain management: a structured literature review and implications for future research. International Journal of Operations \& Production Management 26(7), pp. 703 - 729.

Dimitrov, D. and Saxer, M. (2012). Productivity improvement in tooling manufacture through high speed 5 axis machining. Procedia CIRP 1, pp. 277 - 282.

Fraenkel, J.R. and Wallen, N. (2005). How to Design and Evaluate Research in Education. New York, NY: McGraw Hill.

Gadekar, R.A. and Gadekar, A. (2015). Integration of lean-green manufacturing practices to towards environment friendly products: plastic industry. International Journal of Modern Trends in Engineering and Research 2(2), pp. 255 - 261.

Jensen, S.H. and Jensen K.H. (2007). Implementing of lean manufacturing in SME companies. International Conference on Economic Eng. and Manufacturing Systems, Brasov 8(3), pp. $305-308$.

Krippendorff, K. (2004). Content Analysis: An Introduction to Its Methodology ( $2^{\text {nd }}$ ed.). Thousand Oaks, CA: Sage Publications.

Larson, T. and Greenwood, R. (2004). Perfect complements: synergies between lean production and eco-sustainability initiatives. Environmental Quality Management 13(4), pp. 27 $-36$.

Liker, J.K. (2004). The Toyota Way - 14 Management Principles from the World's Greatest Manufacturer. New York: McGraw-Hill.

Lombard, M., Snyder-Duch, J. and Bracken, C.C. (2002). Content analysis in mass communication: assessment and reporting of intercoder reliability. Human Communication Research, 28, pp. 587-604.

Meyers, F. and Stewart, J. (2002). Motion and Time Study for Lean Manufacturing. $3^{\text {rd }}$ Edition.

Neuendorf, K.A. (2002). The Content Analysis Guidebook. Thousand Oaks, CA: Sage Publications, Inc.

Pearce, A. and Pons, D. (2013). Implementing lean practices: managing the transformation risks. Journal of Industrial $\begin{array}{llllll}\text { Engineering } & \text { pp. } & 1 & - & 19, & \text { DOI: }\end{array}$ http://dx.doi.org/10.1155/2013/790291.

Pusavec, F., Krajnik, P. and Kopac, J. (2010). Transitioning to sustainable production- Part I: Application on machining technologies. Journal of Cleaner Production 18, pp. 174 184.

Puvanasvaran, P., Tian, Suresh, V. and Muhamad, M.R. (2012). Lean principles adoption in environmental management system (EMS): A survey on ISO 14001 certified companies in Malaysia. Journal of Industrial Engineering and Management 5(2), pp. 406 - 430.

Sarantakos, S. (2005). Social Research ( $3^{\text {rd }}$ ed.). New York, NY: Palgrave Macmillan.

Seuring, S. (2004). Industrial ecology, life cycles, supply chains: differences and interrelations. Business Strategy and the Environment 13(5), pp. 306 - 319.

Shahidul, M.I. and Syed S.T. (2011). Dynamics of manufacturing productivity: lesson learnt from labor intensive industries. Journal of Manufacturing Technology Management, 22(5), pp. $664-678$.

Uysal, S. and Madenoglu, C. (2015). A content analysis of scientific research studies on technology leadership in Turkey. Procedia - Social and Behavioral Sciences 191, pp. $37-43$.

Whitelegg, J. (1994). Freight Transport, Logistics and Sustainable Development. London: World wide fund for Nature.

Womack, J.P., Jones, D.T. and Roos, D. (1990). The Machine that Changed the World (New York: Rawson: MacMillan).

Rahul S Mor is currently the Ph.D. Research Scholar in the Department of Industrial \& Production Engineering, National Institute of Technology, Jalandhar, India. His study is focused on 'Investigation of the Competitiveness of Supply Chain practices in Perishable food processing industries'. His research interest includes: Lean Manufacturing, Green Supply Chain Management, Process Improvement, Production Engineering etc; he may be contacted at iersmor@gmail.com

Dr. Sarbjit Singh is currently working as an Associate Professor in the Department of Industrial \& Production Engineering, National Institute of Technology, Jalandhar, India. He has worked as the Head, Department of Industrial \& Production Engineering, and Dy. Dean, Punjab Technical University, Jalandhar. He has about 20 years of research \& teaching experience and his research interest includes: Supply Chain Management, Environmental Planning and Control, Lean Production, Occupational Health \& Safety, Human Factors Engineering etc; he may be contacted at balss@nitj.ac.in

Dr. Arvind Bhardwaj is currently working as Professor in the Department of Industrial \& Production Engineering, National Institute of Technology, Jalandhar, India. He has worked as the Director, Global Institutes, Amritsar; and Head, Department of Industrial \& Production Engineering and Dean, Students Welfare at NIT, Jalandhar. He has about 25 years of research \& teaching experience and his research interests includes: Technology Management, Logistics \& Supply Chain Management, 
Occupational Health \& Safety, Operation Research, Human Factor Engineering etc; he may be contacted at bhardwaja@nitj.ac.in

\section{APPENDIX- I}

Abdulmalek, F.A. and Rajgopal, J. (2007). Analyzing the benefits of lean manufacturing and value stream mapping via simulation: a process sector case study. International Journal of Production Economics 107, pp. 223 - 236.

Ahemad, M., Rehman, A., Shrivastava, R.R. and Shrivastava, R. (2013). Validating green manufacturing framework for sustainable development in an Indian steel industry. University Journal of Mechanical Engineering 1(2), pp. 49 61.

Anand, G. and Kodali, R. (2008). Selection of lean manufacturing systems using the PROMETHEE. Journal of Modelling in Management 3(1), pp. 40 - 70.

Arlbjørn, J.S. and Freytag, P.V. (2013). Evidence of lean: a review of international peer-reviewed journal articles. European Business Review 25(2), pp. 174 - 205.

Baines, T.B., Brown, S., Benedettini, O. and Ball, P. (2012). Examining green production and its role within the competitive strategy of manufacturers. Journal of Industrial Engineering \& Management 5(1), pp. 53 - 87.

Bashkite, V. and Karaulova, T. (2012). Integration of green thinking into lean fundamentals by theory of inventive problems-solving tools. Proceedings of the $23^{\text {rd }}$ International DAAAM Symposium, Vienna 23(1), pp. 345 - 350.

Bergmiller, G.G. and McCright, P.R. (2009). Parallel models for lean and green operations. Proceedings of the Industrial Engineering Research Conference, Miami pp. 1 - 6.

Bose, A.J. and Sinha, S. (2012). Human side of lean production: aren't we on a slippery slope. International Journal of Lean Thinking 3(2), pp. 102 - 116.

Buffa, A. (2009). Lean and green manufacturing program helps Washington's small manufacturers reduce energy use and waste. Apollo News Service pp. 1 - 4.

Carvalho, H. and Machado, V.C. (2011). Integrating lean, agile, resilience and green paradigms in supply chain management. Supply Chain Management pp. 27 - 48, DOI: 10.5772/14592.

Castro, H., Putnik, G. and Shah, V. (2012). A review of agile \& lean manufacturing as issues in selected international / national research \& development programs roadmaps. The Learning Organization 19(3), pp. 267 - 289.

Chahal, V. (2012). An advance lean production system in industry to improve flexibility \& quality in manufacturing by implementation of FMS \& green manufacturing. International Journal of Emerging Technology and Advanced Engineering 2(12), pp. 405 - 408.

Chen, L. and Meng, B. (2010). Why most Chinese enterprises fail in deploying lean production. Asian Social Science 6(3), pp. $52-57$.

Corbett, C.J. and Klassen, R.D. (2006). Extending the horizons: environmental excellence as key to improving operations. Manufacturing and Service Operations Management 8(1), pp. 5 - 22.

Dakov, I. and Novkov, S. (2007). Assessment of the lean production effect on the sustainable industrial enterprise development. Business: Theory and Practice 8(4), pp. 183 188.

Demeter, K. and Matyusz, Z. (2011). The impact of lean practices on inventory turnover. International Journal of Production Economics 133(1), pp. 154 - 163.

Dhingra, R, Das, S. and Kress, R. (2012). Making progress towards more sustainable societies through lean and green initiatives. Journal of Cleaner Production 37, pp. 400 - 402.

Dües, C.M., Tan, K.H. and Lim, M. (2013). Green as the new lean: how to use lean practices as a catalyst to greening your supply chain. Journal of Cleaner Production 40, pp. 93 100 .

Duarte, S. and Cruz-Machado, V. (2013). Modelling lean and green: a review from business models. International Journal of Lean Six Sigma 4(3), pp. 228 - 250.

ElMaraghy, H. and Deif, A.M. (2014). Dynamic modelling of impact of lean policies on production leveling feasibility. CIRP Annals- Manufacturing Technology 63(1), pp. 389 392.

Elmoselhy, S.A. (2013). Hybrid lean-agile manufacturing system technical facet in automotive sector. Journal of Manufacturing Systems 32, pp. 598 - 619.

Elsayed, N.D., Jondral, A. and Greinacher, S. (2013). Assessment of lean and green strategies by simulation of manufacturing systems in discrete production environments. CIRP AnnalsManufacturing Technology 62, pp. 475 - 478.

Esmer, S., Cetin, I.B and Tuna, O. (2010). A simulation for optimum terminal truck number in a Turkish port based on lean and green concept. The Asian Journal of shipping \& logistics 26(2), pp. 277 - 296.

Florida, R. (1996). Lean and green: the move to environmentally conscious manufacturing. California Management Review 39(1), pp. 80 - 105.

Fore, S. and Mbohwa, C.T. (2010). Cleaner production for environmental conscious manufacturing in the foundry industry. Journal of Engineering, Design and Technology 8(3), pp. $314-333$.

Galeazzo, A., Furlan, A. and Vinelli, A (2014). Understanding environmental-operations integration: the case of pollution prevention projects. International Journal of Production Economics 153, pp. 149 - 160.

Ghosh, M. (2012). Lean manufacturing performance in Indian manufacturing plants. Journal of Manufacturing Technology Management 24(1), pp. 113 - 122.

Gustashaw, D. and Hall, R.W. (2008). From lean to green: interface. Association for Manufacturing Excellences Target Magazine 24(5), pp. 6 - 14.

Handa, S., Raj, T. and Grover, S. (2012). Quest for environmental protection by integrated green manufacturing system. National Conference on Trends \& Advances in Mechanical Engg, YMCA University of Science \& Technology, Faridabad, Haryana pp. 930 - 933.

Harrington, D., Khanna, M. and Deltas, G. (2005). Why do firms strive to be green? Explaining the adoption of total quality environmental Management University of Guelph, Ontario 5(1), pp. 1 - 19.

Helldal, M., Tenne, S. and Lindahl, M. (2009). Environmental benefits riding the coattails of lean production- can an integration of environmental aspects and lean production result in synergies \& a reduced risk of sub-optimization? $6^{\text {th }}$ International Symposium on Environmentally Conscious Design and Inverse Manufacturing, Japan pp. 1 - 6.

Herrmann, C., Thiede, S., Stehr, J. and Bergmann, L. (2008). An environmental perspective on lean production, manufacturing systems and technologies for the new frontier. The $41^{\text {st }}$ CIRP Conference on Manufacturing Systems, Tokyo pp. 83 - 88.

Herron, C. and Hicks, C. (2008). The transfer of selected lean manufacturing techniques from Japanese automotive manufacturing into general manufacturing UK) through change agents. Robotics and Computer-Integrated Manufacturing 24(4), pp. 524 - 531.

Hibadullah, S., Fuzi, N., Desa, A. and Zamri, F. (2013). Lean manufacturing practices and environmental performance in 
Malaysian automotive industry. Asian Journal of Finance \& Accounting 5(1), pp. 462 - 471.

Hidy, G.M., Alcorn, W., Clarke, R., Smith, D. and Thomas, V. (2011). Environmental issues and management strategies for waste electronic \& electrical equipment. Journal of the Air \& Waste Management Association 61, pp. 990 - 995.

Holweg, M. (2007). The genealogy of lean production. Journal of Operations Management 25, pp. 420 - 437.

Huang, G.Q., Wright, P.K. and Newman, S.T. (2009). Wireless manufacturing: a literature review, recent developments and case studies. International Journal of Computer Integrated Manufacturing 22(7), pp. 1 - 16.

Ioppolo, G., Cucurachi, S., Salomone, R., Saija, G. and Ciraolo, L. (2014). Industrial ecology and environmental lean management: lights and shadows. Sustainability 6, pp. 6362 6376.

Jacobs, B.W., Singhal, V.R. and Subramanian, R. (2010). An empirical investigation of environmental performance and the market value of the firm. Journal of Operations Management 28, pp. 430 - 441.

Jadhav, J.R., Mantha, S.S. and Rane, S.B. (2013). Practice bundles for integrated green-lean manufacturing systems. International Journal of Computer Applications pp. 28 - 32.

Jaganathan, V.P. (2014). Line balancing using candidate rule algorithm in a garment industry: a case study. International Journal of Lean Thinking 5(1), pp. 1 - 11.

Johansson, G. and Sundin, E. (2014). Lean and green product development: two sides of the same coin? Journal of Cleaner Production, 85 pp. 104 - 121.

Keitany, P. and Riwo, A.M. (2014). Effects of lean production on organizational performance: a case study of flour producing company in Kenya. European Journal of Logistics Purchasing and Supply Chain Management 2(2), pp. 1 - 14.

Khalid, S. (2011). Productivity improvement of a motor vehicle inspection station using motion and time study techniques. Journal of King Saud University 23(1), pp. 33 - 41.

Kidwell, M. (2006). Lean manufacturing, the environment and the bottom line: ignoring the $8^{\text {th }}$ deadly waste leaves money on the table. Greenbiz 22(6), pp. $13-18$.

King, A. (2007). Cooperation between corporations and environmental groups: a transaction cost perspective. Academy of Management Review 32(3), pp. 889 - 900.

Kurdve, M., Zackrisson, M., Wiktorsson, M. and Harlin, U. (2014). Lean and green integration into production system modelsexperiences from Swedish industry. Journal of Cleaner Production 185, pp. 189 - 190.

Kurdve, M., Hanarp, P., Chen, X., Qiu, X., Zhang, Y., Stahre, J. and Laring, J. (2011). Use of environmental value stream mapping and environmental loss analysis in lean manufacturing work at Volvo. Proceedings of the $4^{\text {th }}$ Swedish Production Symposium, SPS11.

Kyrö, R., Luoma, T., Junnila, S. and Määttänen, E. (2011). Linking lean to green- energy efficiency as a value stream. $10^{\text {th }}$ Euro FM Research Symposium, Vienna pp. 1 - 9.

Laird, J. (2012). Lean and green. Energy Savings in Manufacturing pp. $71-77$.

Latha, P. and Inbasekaran, S. (2014). A study on environmentally aware business models lean, green, zero waste technology and CSR. International Journal of Science and Research 3(7), pp. $537-542$.

Liu, Y., Dong, H., Lohse, N., Petrovic, S. and Gindy, N. (2014). An investigation into minimizing total energy consumption \& weighted tardiness in job shops. Journal of Cleaner Production 65, pp. 87 - 96.

Maia, L.C., Alves, A.C. and Leão, C.P. (2013). Sustainable work environment with lean production in textile and clothing industry. International Journal of Industrial Engineering and Management 4(3), pp. 183 - 190.

Marudhamuthul, R. and Krishnaswamy, M. (2011). The development of green environment through lean implementation in a garment industry. ARPN Journal of Engg and Applied Sciences 6(9), pp. 104 - 111.

Marudhamuthul, R., Krishnaswamy, M. and Pillai, D.M. (2011). The development and implementation of lean manufacturing techniques in Indian garment industry. Jordan Journal of Mechanical and Industrial Engineering 5(6), pp. 527 - 532.

Marvel, J.H. and Standridge, C.R. (2009). A simulation-enhanced lean design process. Journal of Industrial Engineering and Management 2(1), pp. 90 - 113.

Maxwell, J., Briscoe, F., Schenk, B. and Rothenberg. (1998). Can lean production practices increase environmental performance- case study: Honda, America. Environmental Quality Management pp. 53 - 61.

Mcleod, A. (2009). Conceptual development of an introductory lean manufacturing course for freshmen and sophomore level students in industrial technology. The Technology Interface Journal 10(1), pp. 1 - 10.

Miller, G., Pawloski, J. and Standridge, C. (2010). A case study of lean, sustainable manufacturing. Journal of Industrial Engineering \& Management 3(1), pp. 11 - 32.

Mittal, V.K. and Sangwan, K.S (2014). Development of a structural model of environmentally conscious manufacturing drivers. Journal of Manufacturing Technology Management 25(8), pp. 1195 - 2008.

Moreira, F., Alves, A.C. and Sousa, R.M. (2010). Towards ecoefficient lean production systems. IFIP Advances in Information and Communication Technology 322, pp. 100 108.

Nasab, H.H., Dehghani, M. and Nasab, A.H. (2013). Analysis of technology effectiveness of lean manufacturing using system dynamics. ISRN Industrial Engineering pp. 1 - 10.

Netland, T.H. and Aspelund, A. (2014). Multi-plant improvement programmes: a literature review and research agenda. International Journal of Operations \& Production Management 34(3), pp. $390-418$

Nordhaus, W.D. (1995). The ghosts of climates past and the specters of climate change future. Energy Policy, 23(4/5), pp. $269-282$

Nulkar, G. (2014). Does environmental sustainability matter to small and medium enterprises? International Journal of Environmental Studies 71(4), pp. 481 - 489.

Ogunbiyi, O.E., Oladapo, A.A. and Goulding, J.S. (2013). A review of lean concept and its application to sustainable construction in the UK. International Journal of Sustainable Construction Engineering \& Technology, 4(2), pp. 82 - 92.

Omer, A.M. (2008). Green energies and the environment. Renewable and Sustainable Energy Reviews 12, pp. 1789 1821.

Omega. (2011). Lean manufacturing implementation in Malaysian automotive components manufacturer: a case study. Proceedings of the World Congress on Engineering 1, pp. 772 - 776.

Olhager, J. and Parjago, D. (2012). The impact of manufacturing and supply chain improvement initiatives: a survey comparing make-to-order and make-to-stock firms. Omega 40(2), pp. $159-165$.

Pampanelli, A.B., Found, P. and Bernardes A.M. (2011). A lean and green Kaizen model. POMS Annual Conference, Nevada pp. 1 - 23.

Pauline, A.F. (2009). Lean and low environmental impact manufacturing. POMS $20^{\text {th }}$ Annual Conference, Orlando pp. $1-7$.

Post, C. and Slaughter, J. (2000). Lean production: why work is worse than ever and what's the alternative? Solidarity Working Paper pp. 1 - 7.

Prasad, S. and Sharma, S.K. (2014). Lean and green manufacturing: concept and its implementation in operations. International Journal of Advanced Mechanical Engineering 4(5), pp. 509 - 514. 
Prasad, S. and Sharma, S.K. (2014). Studies linking lean manufacturing methodology with green manufacturing. Journal of Energy Research and Environmental Technology $1(1)$, pp. $34-37$.

Puvanasvaran, A., Perumal, A., Robert, K.S., Suresh, A.V. and Muhamad, R. (2012). Integration model of ISO 14001 with lean principles. American Journal of Applied Sciences 9(12), pp. 1974 - 1978.

Purvis, L., Gosling, J. and Naim, M.M. (2014). Development of a lean, agile and leagile supply network taxonomy based on types of flexibility. International Journal of Production Economics 151, pp. 100 - 111.

Puvanasvaran, P., Tian, R.K., Suresh, V. and Muhamad, M.R. (2012). Lean principles adoption in environmental management system EMS: a survey on ISO 14001 certified companies in Malaysia. Journal of Industrial Engineering and Management 5(2), pp. 406 - 430.

Rakshit, N.H. and Rodrigues, L. (2013). Lean transformation for green and financially viable foundries. International Journal of Mechanical and Production Engineering 2(1), pp. 118 134.

Ramirez, E., Gonzalez, R.J. and Moreira, G.J. (2014). Barriers and bridges to the adoption of environmentally sustainable offerings. Industrial Marketing Management 43, pp. 16 - 24.

Robert, B.P. (2008). Framing your lean-to-green effort. Environmental Quality Management pp. 85 - 93.

Romvall, K., Wiktorsson, M. and Bellgran, M. (2010). Competitiveness by integrating the green perspective in production- a review presenting challenges for research and industry. Flexible Automation and Intelligent Manufacturing, FAIM, California pp. 1 - 8.

Rosenbaum, S., Toledo, M. and Gonzalez, V. (2012). Green-lean approach for assessing environmental \& production waste in construction. Proceedings- $20^{\text {th }}$ Annual Conference of the International group for Lean Construction, San Diego pp. 1 10.

Roosen, T.J. and Pons, D.J. (2013). Environmentally lean production: the development and incorporation of an environmental impact index into VSM. Journal of Industrial Engineering pp. 1 - 17.

Salleh, N.A., Kasolang, S. and Jaffar, A. (2012). Green lean total quality information management in Malaysian automotive companies. Procedia Engineering 41, pp. 1708 - 1713.

Satao, S.M., Thampi, G.T., Srinivas, B., Patil, B.T. and Dalvi, S.D. (2012). Enhancing waste reduction through lean manufacturing tools \& techniques: a methodical step in territory of green manufacturing. International Journal of Research in Management \& Technology 2(2), pp. 253 - 257.

Sawhney, R., Teparakul, P., Bagchi, A. and Li, X. (2007). EnLean: a framework to align lean and green manuf. in metal cutting supply chain. International Journal of Enterprise Network Management 1(3), pp. 238 - 260.

Shah, R. and Ward, P.T. (2007). Defining and developing measures of lean production. Journal of Operations Management 25, pp. $785-805$.

Silva, C., Vaz, P. and Ferreira, L.M. (2013). The impact of lean manufacturing on environmental and social sustainability: a study using a concept mapping approach. $6^{\text {th }}$ International Conference on Management and Control of Production and Logistics, Fortaleza, Brazil 6(1), pp. 306 - 310.

Singh, B., Garg, S.K. and Sharma, S.K. (2010). Development of index for measuring leanness: study of an Indian auto component industry. Measuring Business Excellence 14(2), pp. $46-53$.

Sujatha, R. and Basu, S. (2013). Human resource dimensions for environment management system: evidence from two Indian fertilizer firms. European Journal of Business and Management 5(9), pp. 54 - 61.
Sullivan, W.G., McDonald, T.N. and Aken, E.M. (2002). Equipment replacement decisions and lean manufacturing. Robotics and Computer Integrated Manufacturing 18, pp. $255-265$.

Taggart, P. and Kienhöfer, F. (2013). The effectiveness of lean manufacturing audits in measuring operational performance improvements. South African Journal of Industrial Engineering 24(2), pp. 140 - 154.

Taubitz, M.A. (2010). Lean, green \& safe: integrating safety into the lean, green and sustainability movement. American Society of Safety Engineers pp. 39 - 46.

Thackeray. (2008). M. Lean green thinking in operations- a study of General Cable. pp. 6 - 8.

Li, H., Zhang, P. and Li, X. (2011). The research of the application domain of lean design. $18^{\text {th }}$ International Conference on Industrial Engineering and Management 1, pp. 259 - 261.

Torielli, R.M., Abrahams, R.A., Smillie, R.W. and Voigt, R.C. (2010). Using lean methodologies for economically \& envi. sustainable foundries. The $69^{\text {th }}$ WFC paper, Hangzhou, 8(1), pp. $74-88$.

Treville, S. and Antonakis, J. (2006). Could lean production job design be intrinsically motivating? Contextual, configurational, and levels-of-analysis issues. Journal of Operations Management 24, pp. 99 - 123.

Upadhye, N., Awana, D.S. and Mathur, S. (2014). Interpretive structural modeling of implementation enablers for Just-inTime in ICPI. International Journal of Lean Thinking 5(1), pp. 1 - 16 .

Venkataramana, K., Ramnath, B.V., Kumar, V.M., Elanchezhian, C. (2014). Application of value stream mapping for reduction of cycle time in a machining process. Procedia Materials Sc. 6, pp. $1187-1196$

Venkat, K. and Wakeland, W. (2006). Is lean necessarily green? Proceedings of $50^{\text {th }}$ Annual Meeting of the ISSS pp. $1-16$.

Vivek, N. and Ravindran, S. (2008). An empirical study on the impact of environmental uncertainty on the lean practices of small manufacturing firms- a supply chain perspective. Journal of Contemporary Research in Management pp. 113 124.

Wang, L., Ming, X.G., Kong, F.B., Li, D. and Wang, P. (2011). Focus on implementation: a framework for lean product development. Journal of Manufacturing Technology Management 23(1), pp. 4 - 24

Wiengarten, F. and Pagell, M. (2012). The importance of quality management for the success of environmental management initiatives. International Journal of Production Economics 140, pp. $407-415$.

Whitman, L., Twomey, J. and Cheraghi, S. (2008). Lean and green production systems class project. American Society for Engineering Education pp. 1 - 9.

Yang, C.L., Lin, S.P., Chan, Y. and Sheu, C. (2010). Mediated effect of environmental mgt on manuf. competitiveness: an empirical study. International Journal of Production Economics 123, pp. 210 - 220.

Yang, M.G., Hong, P. and Modi, S.B. (2011). Impact of lean manufacturing and environmental Management on business performance: an empirical study of manufacturing firms. International Journal of Production Economics 129, pp. 251 $-261$.

Yang, Y., Jiafu, T., Wei, S., Yong, Y. and Ikou, K. (2013). Reducing workers by converting assembly line into a pure cell system. International Journal of Production Economics 145 , pp. $799-806$. 